\title{
CUTANEOUS LARVA MIGRANS IN EARLY INFANCY: A UGANDAN CASE REPORT
}

\author{
Eria Muwanguzi ${ }^{1}$, Mubaraka Kayiira ${ }^{1}$, Derrick Kasozi ${ }^{1}$, and Enos Kigozi ${ }^{2}$ \\ ${ }^{1}$ Makerere University \\ ${ }^{2}$ Medecins Sans Frontieres
}

September 25, 2021

\begin{abstract}
Helminths are an important cause of infection in poorly developed countries. The Majority spread with soil to skin contact. In unusual patients presenting below 1 year, treatment can be challenging. The disease can be self-limiting, treatment reduces progression to serious disease. Here, we present a three-month-old with Cutaneous Larva Migrans.
\end{abstract}

Hosted file

Cutaneous Larva Migrans.docx available at https://authorea.com/users/437602/articles/539121cutaneous-larva-migrans-in-early-infancy-a-ugandan-case-report 